\title{
Influence of Remineralizing Agents on the Surface Roughness of Eroded Dental Enamel: in Vitro Study
}

\author{
Influência de Agentes Remineralizantes na Rugosidade Superficial do Esmalte Dental \\ Erodido: um Estudo in Vitro
}

Cesar Penazzo Lepri*a; Rayssa Prado Macedoa; Vanessa Ferreira Marraa; Gabriella Rodovalho Paiva ${ }^{a}$; Denise Tornavoi De Castro ${ }^{a}$; Vinicius Rangel Geraldo Martins ${ }^{\mathrm{a}}$; Juliana Jendiroba Faraoni ${ }^{\mathrm{b}}$; Maria Angélica Hueb De Menezes Oliveira ${ }^{\mathrm{a}}$; Regina Guenka Palma-Dibb ${ }^{\mathrm{b}}$; Janisse Martinelli de Oliveira Misiarac;

\author{
${ }^{a}$ School of Dentistry, University de Uberaba, Uberaba-MG, Brazil. \\ ${ }^{b}$ Ribeirao Preto School of Dentistry, University of Sao Paulo, Sao Paulo-SP, Brazil. \\ ${ }^{\mathrm{c}}$ Centro de Formação Profissional, Cefores, University of Triangulo Mineiro, Uberaba-MG, Brazil. \\ *E-mail: cesar.lepri@uniube.br \\ Recebido em: 30/01/2020 \\ Aprovado em: 30/04/2020
}

\begin{abstract}
The objective of this in vitro study was to evaluate the influence of remineralizing agents on the surface roughness of eroded tooth enamel. Forty incisive bovines were selected and sectioned to obtain specimens of $4 \mathrm{~mm} \mathrm{X} 4 \mathrm{~mm}$, resulting in a surface area of $16,00 \mathrm{~mm}^{2}$, with a thickness of $2.50 \mathrm{~mm}$. The specimens were immersed in lemon juice, twice a day, over 5 days, and randomly divided into the following 4 groups: G1 $=$ No treatment; G2 $=1.23 \%$ APF; G3 = Fluoride Varnish 5\% and G4 = Regenerated. The surface roughness of the specimens was analyzed by means of confocal laser scanning microscopy. The obtained data were submitted to ANOVA after attend the homogeneity (Levene's) and normality tests (Kolmogorov-Smirnov). All tests were statistically significant at $5 \%(\alpha=0.05)$. The results showed that there was no statistically significant difference on the enamel roughness surface area between groups in the experimental region and the founded values were higher at the experimental when compared to the control region, however, without differences between the groups in each region. It was concluded that the remineralizing agents were not able to reduce the surface roughness of the studied groups.
\end{abstract}

Keywords: Tooth Erosion. Dental Enamel. Fluorine. Tooth Remineralization.

\section{Resumo}

O objetivo deste estudo in vitro foi avaliar a influência de agentes remineralizantes na rugosidade da superficial do esmalte dental erodido. Quarenta bovinos incisivos foram selecionados e seccionados para obter espécimes de $4 \mathrm{~mm} \times 4 \mathrm{~mm}$, resultando em uma área superficial de 16,00 mm², com espessura de 2,50 mm. As amostras foram imersas em suco de limão, duas vezes ao dia, durante 5 dias, e divididas aleatoriamente nos 4 grupos seguintes: G1 = Sem tratamento; G2 = Flúor gel 1,23\%; G3 = Verniz fluoretado 5\% e G4 =Regenerate. A rugosidade superficial das amostras foi analisada por microscopia confocal de varredura a laser. Os dados obtidos foram submetidos à ANOVA após os testes de homogeneidade (Levene) e normalidade (Kolmogorov-Smirnov). Todos os testes foram estatisticamente significantes a $5 \%(\boldsymbol{\alpha}=0,05)$. Os resultados mostraram que não houve diferença estatisticamente significante na rugosidade de área do esmalte entre os grupos na região experimental e os valores encontrados foram maiores na experimental quando comparados à região controle, no entanto, sem diferenças entre os grupos em cada região. Concluiu-se que os remineralizantes não foram capazes de reduzir a rugosidade da superficie dos grupos estudados.

Palavras-chave: Erosão Dentária. Esmalte dentário. Flúor. Remineralização Dentária.

\section{Introduction}

Dental erosion is defined as the irreversible loss of tooth structure due to the effect of acidic substances on the teeth surface without bacterial involvement. ${ }^{1}$ Initiated at the enamel, the erosion can advance into dentin because the acids dissolves the inorganic dental hard tissue what cause the increase of the surface roughness resulting in the decrease of the microhardness and the mechanical resistance of the superficial dental layer. ${ }^{2,3}$

Non-bacterial acids that causes dental erosion could be from gastric acids in patients with anorexia nervosa, bulimia, hyperthyroidism and gastroesophageal disorder or others. ${ }^{4}$ Furthermore, the changes in dietary patterns with the increase of the consumption of acidic/erosive food and beverages like juices, sodas, isotonic and energy drinks affect the incidence of dental erosive disease. ${ }^{4}$

The eroded enamel presents increase in the surface roughness that increase the dental susceptibility to new acidic etching and the abrasiveness to the opposite teeth besides to facilitate the formation and adhesion of bacterial biofilm, what rises the occurrence and the progression of dental caries and periodontal diseases. ${ }^{5,6}$

The consolidated prevention treatment to dental erosion is the topical application of different fluoride compounds like dentifrice, mouth rinse solutions and gels, and varnishes, to increase the resistance of teeth to acid challenges. ${ }^{7}$ Fluoride compounds are effective in dental remineralization increasing tooth acid resistance after an acid challenge ${ }^{8}$ because in high 
concentrations they promote the precipitation of a calcium fluoride layer in the enamel ${ }^{9}$ that acts as a barrier on this surface, acting as a fluoride reservoir inhibiting contact of the acids with the dental surface..$^{8,10-13}$

Furthermore, the use of a calcium silicate and sodium phosphate-based toothpaste presented great results as a treatment to erosive dental lesions because its regular use can promote mineral regeneration at the enamel surface. ${ }^{8}$

Thus, the present study analyzed the influence of different remineralizing agents on the treatment of acid erosion in dental enamel by the evaluation of surface roughness $\left(\mu \mathrm{m}^{2}\right)$ with confocal laser scanning microscopy. The null hypothesis of this study was that the erosive challenge and the different surfaces treatments would not result in statistically significant differences in surface roughness values.

\section{Material and Methods}

\subsection{Teeth Selection}

Forty specimens were obtained from forty bovine incisors that were selected without the presence of cracks and wear. The teeth were cleaned and then immersed in a $10 \%$ formalin solution $(\mathrm{pH}=7)$ for 7 days for disinfection. These teeth were then washed and stored in distilled and deionized water at a temperature of $4^{\circ} \mathrm{C}$, changed daily for a period of 7 days.

\subsection{Preparation of Specimens}

The incisors were selected by separating the coronary portion of the root using a refrigerated diamond disk on a cutting machine. The first cut was made $1 \mathrm{~mm}$ above the enamel-cement junction. The second cut was performed in the mesiodistal, obtaining three parts (cervical, middle and incisal third). The middle third of the crown was resected to obtain specimens in the initial dimensions of $4.25 \mathrm{~mm} \times 4.25 \mathrm{~mm}$. The specimens had their sides adjusted using \# 600 sandpaper under cooling water to $4 \mathrm{~mm} \times 4 \mathrm{~mm}$ standardization, resulting in a surface area of $16 \mathrm{~mm}^{2}$. Exterior surface polishing (vestibular) was performed on polishing machine using the following sanding sequence: \# 320 for 15 seconds; \# 600 for 20 seconds, \# 1200 for 30 seconds. Finally, felt and alumina disc polishing was performed for 30 seconds for the initial standardization of all specimens. Variations in size were allowed by $10 \%$, plus or minus.

Half of the surface of each specimen was covered with adhesive tape. Two layers of red cosmetic nail polish enamel and sculpt wax were applied, making the waterproofing of the specimens. After this procedure, the insulating tape was removed, and each specimen was left with half of the free surface of the protection made with nail polish enamel and wax.

The specimens were stored in distilled and deionized water at a temperature of $4{ }^{\circ} \mathrm{C}$ and the erosive challenge was performed on the specimens that were randomly divided into 4 groups $(\mathrm{n}=10)$, where each group received their treatment.

\subsection{Erosive Challenge}

The specimens were submitted to erosive challenge in lemon juice (Del Valle - The Coca-Cola Company, Ribeirão Preto, SP, Brazil) that presented the $\mathrm{pH}$ of 2.8 at the temperature of $10{ }^{\circ} \mathrm{C}$ (PG1800 digital pHmeter, GEHAKA). Each group was placed separately on a Becker for 1 minute on a magnetic stirrer. After, the erosive solution was discarded, and the specimens washed with distilled and deionized water for 10 seconds and stored again in distilled water and placed in the oven at $37{ }^{\circ} \mathrm{C}$ between cycles. This procedure was performed twice a day, with minimum intervals of 2 hours between challenges, for a total period of 5 days, after that the specimens were conditionate at a distilled water until the next day, when the different proposed treatments were performed.

\subsection{Specimen treatment}

The treatments were $(n=10)$ : G1- no treatment (control group); G2- 1.23\% fluoridated gel; G3- 5\% fluoride varnish; G4- REGENERATE®.

The $1.23 \%$ Acidulated Phosphate Fluoride (APF) (Fluoride Gel - Nova DFL) and 5\% Sodium Fluoride Varnish, Duraphat $\AA$ were applied at the surface of its respective samples with a disposable applicator (Microbush $\AA$ ) for 4 minutes, and the REGENERATE Enamel Science ${ }^{\mathrm{TM}}$ Biphasic Silicate/ Phosphate Gel were applied for 1 minute at the samples. The excesses of the products were removed with a sterile gauze.

\subsection{Surface roughness analysis}

After the erosive challenge, followed by the application of the surface treatments agents, the topographic profile 3D was analyzed (wear profile), with the purpose of checking the surface roughness in the different experimental groups by a confocal laser scanning (OLS4000®).

\subsection{Statistical Analysis}

The obtained data were analyzed for distribution (Levene) and normality (Kolmogorov-Smirnov). Once these conditions were satisfied, the statistical analysis of variance (ANOVA) was performed, with a significance level of $5 \%(\alpha=0.05)$ using the SPSS 17.0 software.

\section{Results and Discussion}

The surface roughness results $\left(\mu \mathrm{m}^{2}\right)$ of the present study are described in Table 1 below.

Table 1 - Mean values (standard deviation) of the surface roughness of area $\left(\mu \mathrm{m}^{2}\right)$ of the control and experimental (after treatments) specimen regions for the groups

\begin{tabular}{|c|c|c|}
\hline Groups & Control Region & Experimental Region \\
\hline G1 & $0.451(0.032)^{\mathrm{a}}$ & $2.587(0.087)^{\mathrm{b}}$ \\
\hline G2 & $0.412(0.027)^{\mathrm{a}}$ & $2.612(0.054)^{\mathrm{b}}$ \\
\hline G3 & $0.433(0.039)^{\mathrm{a}}$ & $2.512(0.094)^{\mathrm{b}}$ \\
\hline G4 & $0.457(0.035)^{\mathrm{a}}$ & $2.497(0.107)^{\mathrm{b}}$ \\
\hline
\end{tabular}

different letters represent statistically significant difference $(\mathrm{p}<0.05)$. Source: Research data. 
In the control region, it was observed that there was no statistically significant difference between the groups. For the experimental region, there was an increase in surface roughness values for all groups with a statistically significant difference when compared to the control region $(p<0.05)$, but without differences between them.

After the surface roughness analysis results, it was found that the null hypothesis of the present study was partially rejected, since the roughness values founded after erosion were higher when compared to the control region and the surface treatments were not effective to recover the enamel integrity of the specimens.

In the present study, bovine teeth were used at the experimental test as a substitute for human teeth because the chemical composition and physical features of bovine enamel are similar to those of human teeth. ${ }^{14}$ In addition, bovine incisors are frequently used in dental research due to the difficult to obtain intact human teeth, ${ }^{15}$ and its larger surface allow the use of demineralization and remineralization researches. ${ }^{5,6,8,16,17}$

In this study it was observed that there was no significant difference in statistical values between the groups of the control region, that indicates that the waterproofing of the specimens with the nail enamel and sticky wax was effective (Table 1). However, in the experimental region of the specimens the values of surface roughness presented statistical similar values between the groups and statistically higher when compared with that obtained at the control region (Table 1).

The founded results show that the use of the lemon juice as a demineralizing agent attempting to cause extrinsic factor erosion in tooth enamel was effective due to exposure to acid juice since acid beverage consumption is one of a causal factors of dental erosion. ${ }^{18}$ In the present study the $\mathrm{pH}$ of the erosive drink used was 2.8 at a temperature of $10^{\circ} \mathrm{C}$, below to 5.5 and 6.5 that are the critic $\mathrm{pH}$ of enamel and dentin, respectively, ${ }^{19}$ thus showing that the utilized juice has an acidic $\mathrm{pH}$ enough to cause tooth demineralization by increasing the surface roughness at the enamel. It probably occurs because at low $\mathrm{pH}$ like that observed for the lemon juice, the amount of $\mathrm{H}^{+}$increases, wakening the binding of $\mathrm{Ca}^{+2}$ ions, leading then into solution, ${ }^{16}$ changing the enamel surface by the increasing at the surface roughness, what was observed in this study (Table 1). Other authors found by SEM images analyses that citric fruit juice caused morphological changes to the enamel surface, including the presence of craters and surface irregularities. $^{16}$

The tested treatments for the erosion in this study were the application of $1.23 \%$ APF, $4 \%$ fluoride varnish and Regenerate, which has been used as a clinical treatment of demineralized enamel. ${ }^{20}$ However, the tested materials were not capable to repair the surface roughness of the specimens after the acid challenge. This can be explained because the fluoride treatments can form fluoridated apatites in the enamel structure and accelerate the deposition of $\mathrm{CaF}_{-2}$-like material and calcium phosphate from the supersaturated gel. ${ }^{16,19}$ Besides, the fluoride can result in lower $\mathrm{pH}$, making calcium available for interaction with fluoride in the form of a layer of $\mathrm{CaF}_{2} \cdot{ }^{16}$

Conversely, although the calcium silicate and sodium phosphate-based material can to release calcium ions to the surrounding oral fluids under acid conditions, to inhibit the enamel hydroxyapatite solution and to buffer the protons absorption at the eroded enamel surface,,${ }^{14}$ in the present study, the Regenerate application did not promote the decrease of the surface roughness at the enamel. This can be justified because of the protocol utilized in this study, where it was done one application of the material, being indicate the continuous use to obtain the recovering of the integrity of the enamel damage surface. ${ }^{14}$

The preventive effects of different types of fluoride on erosion injuries have positive results. ${ }^{21}$ As the unsuccessful obtained results in the present study to fluoride and calcium silicate and sodium phosphate-based materials, an alternative treatment could be adopted is the enamel erosion prevention. The analyzed materials did not have the ability to naturally restore the tooth with erosion already in place, however, they could be used to prevent the enamel erosion. ${ }^{17}$

\section{Conclusion}

Considering the results obtained in the present study, remineralizing agents were not able to reduce the surface roughness of the studied groups, demonstrating the importance of adopting preventive strategies.

\section{Funding}

This study was financed in part by the Coordenação de Aperfeiçoamento de Pessoal de Nível Superior - Brasil (CAPES) - Finance Code 001, by the Fundação de Amparo à Pesquisa do Estado de Minas Gerais (FAPEMIG) and by the Programa Institucional de Apoio a Pesquisa (PAPE-UNIBE).

\section{References}

1. Ganns C. Is erosive tooth wear an oral disease? Monogr Oral Sci 2014;25:16-2. doi: https://doi.org/10.1159/000359931

2. Machado CM, Zamuner AC, Modena KCS, Ishikiriama SK, Wang L. How erosive drinks and enzyme inhibitors impact bond strength to dentin. Braz Oral Res 2015;29(1):1-7. doi: 10.1590/1807-3107BOR-2015.vol29.0105

3. Kanzow P, Wegehaupt FJ, Attin T, Wiegand A. Etiology and pathogenesis of dental erosion. Quintessence Int 2016;47(4):275-8. doi: 10.3290/j.qi.a35625Corpus ID: 207609680

4. Poggio C, Gulino C, Mirando M, Colombo M, Pietrocola G. Preventive effects of different protective agents on dentin erosion: An in vitro investigation J Clin Exp Dent 2017;9(1):e7-12. doi:10.4317/jced.53129

5. Soares LES, Carvalho-Filho ACB Protective Effect of Fluoride Varnish and Fluoride Gel on Enamel Erosion: Roughness, SEM-EDS, and m-EDXRF Studies. Microsc Res and Tech 2015;78(3):240-8. doi: https://doi.org/10.1002/ 
jemt.22467

6. Nogueira RD, Silva CB, Lepri CP, Palma-Dibb RG, GeraldoMartins VR. Evaluation of Surface Roughness and Bacterial Adhesion on Tooth Enamel Irradiated with High Intensity Lasers. Braz Dent J 2017; 28(1):24-9. doi: https://doi. org/10.1590/0103-6440201701190

7. Ramalho KM, Eduardo CP, Heussen N, Rocha RG, Meyer-Lueckel H, Lampert F, Apel C, Esteves-Oliveira M. Randomized in situ study on the efficacy of $\mathrm{CO} 2$ laser irradiation in increasing enamel erosion resistance. Clin Oral Investig 2019;23(5):2103-12. doi: 10.1007/s00784-0182648-y

8. Ferreira JB, Paiva GR, Geraldo-Martins VR, Faraoni JJ, Dibb RGP, Lepri CP. Influence of Remineralizing Dentifrice in the Treatment of Erosive Enamel Lesions. J Health Sci 2018;20(4):238-42. doi: http://dx.doi.org/10.17921/24478938.2018v20n4p238-242

9. Fernández CE, Tenuta LMA, Cury AADB, Nóbrega DF, Cury JA. Effect of 5,000 ppm fluoride dentifrice or 1,100 ppm fluoride dentifrice combined with acidulated phosphate fluoride on caries lesion inhibition and repair. Caries Res 2017;51(3):179-87. doi: https://doi.org/10.1159/000453624

10. Comar LP, Cardoso CDAB, Charone S, Grizzo LT, Buzalaf MAR, Magalhaes AC. TiF4 and NaF varnishes as antierosive agents on enamel and dentin erosion progression in vitro. J Appl Oral Sci 2015;23(1):14-8. doi: https://doi. org/10.1590/1678-775720140124

11. Gao SS, Zhang S, Mei ML, Lo EC, Chu CH. Caries remineralisation and arresting effect in children by professionally applied fluoride treatment: a systematic review. BMC Oral Health 2016;16:12. doi:10.1186/s12903016-0171-6

12. Bezerra SJC, Trevisan LR, Viana IEL, Lopes RM, Pereira DL, Aranha ACC, Scaramucci T. Er,Cr:YSGG laser associated with acidulated phosphate fluoride gel $(1.23 \% \mathrm{~F})$ for prevention and control of dentin erosion progression. Lasers in Med Sci 2018;34(3):449-55. doi: https://doi.org/10.1007/ s10103-018-2609-3
13. Godoi FA, Carlos NR, Bridi EC, Amaral FLD, França FMG, Turssi CP, Kantovitz KR, Basting RT. Remineralizing effect of commercial fluoride varnishes on artificial enamel lesions. Braz Oral Res 2019;33:e044. doi: https://doi. org/10.1590/1807-3107bor-2019.vol33.0044.

14. Falla-Sotelo F, Rizzutto M, Tabacniks M, Added N, Barbosa M, Markarian R, Youssef, M. Analysis and discussion of trace elements in teeth of different animal species. Braz J Physics 2005;35(3B):761-2. doi: http://dx.doi.org/10.1590/S010397332005000500010

15. Steiger-Ronay V, Tektas S, Attin T, Lussi A, Becker K, Wiedemeier DB, Carvalho TS. Comparison of Profilometric and microindentation analyses for determining the impact of saliva on the abrasion of initially eroded enamel. Caries Res 2019;53(1):33-40. doi: https://doi.org/10.1159/000489133

16. Soares LES, Magalhães JS, Marciano FR, Lobo AO. Surface characteristics of a modified acidulated phosphate fluoride gel with nano-hydroxyapatite coating applied on bovine enamel subjected to an erosive environment. Microsc Res Tech 2018;81:1456-66. doi: 10.1002/jemt.23146

17. Arantes BF, De Oliveira LM, Palma-Dibb RG, Faraoni JJ, De Castro DT, Geraldo-Martins VR, Lepri CP. Influence of Er,Cr:YSGG laser, associated or not to desensitizing agents, in the prevention of acid erosion in bovine root dentin. Lasers Med Sci 2019;34(5):893-900. doi: https://doi.org/10.1007/ s10103-018-2669-4

18. Ostrowska A, Szymański W, Kołodziejczyk L, Bołtaczrzepkowska E. Evaluation of the Erosive Potential of Selected Isotonic Drinks: In Vitro Studies. Adv Clin Exp Med 2016;25(6):1313-9. doi: 10.17219/acem/62323

19. Nanci A. Ten cate's oral histology. St. Louis:: Elsevier; 2017.

20. Sancakli HS, Austin RS, Al-Saqabi F, Moazzez R, Bartlett D. The influence of varnish and high fluoride on erosion and abrasion in a laboratory investigation. Aust Dent J 2015;60:38-42. doi: 10.1111/adj.12271

21. Lussi A, Carvalho TS. The future of fluorides and other protective agents in erosion prevention. Caries Res 2015;49 Suppl 1:18-29. doi:10.1159/000380886 